\title{
Disinventing Native Speakerism in English Language Teaching
}

\author{
Junshuan Liu $^{1}$ \\ ${ }^{1}$ School of Foreign Languages, Pingdingshan University, Pingdingshan, Henan, China \\ Correspondence: Junshuan Liu, School of Foreign Languages, Pingdingshan University, Weilai Road, New City \\ District, Pingdingshan, 467000, Henan, China.
}

Received: October 4, 2021

doi: $10.5539 /$ elt.v14n11p97
Accepted: October 25, 2021

Online Published: October 27, 2021

URL: https://doi.org/10.5539/elt.v14n11p97

\begin{abstract}
This article explores native speakerism, a chauvinistic ideology, in reference to relevant literature. It first exposes its ideological essence and adverse effects on English language teaching (ELT), and then moves to deconstruct the native speakerist practices concerning English language teachers, English language norm, cultural foundation of ELT curriculum, and teaching methodology, particularly the approaches of communicative language teaching (CLT) and task-based language teaching (TBLT). Through unearthing the culturist essence of native speakerism and the fallacies embedded in native speakerist ELT practices, this study is intended to contribute to eliminating native speakerism and building up more equitable and harmonious ELT profession.
\end{abstract}

Keywords: native speakerism, fallacy, NS teachers, NS English, NS culture, CLT/TBLT

\section{Introduction}

Native speakerism (Holliday, 2005) as a culturist pro-nativeness ideology has been vibrating in all sectors of English language teaching (ELT) around the world, with ELT ecology constantly devastated. During the past three decades, an abundant amount of studies have been conducted on this ideology and its pernicious effects. However, most studies concentrate on the issues regarding English language teachers (Liu \& Li, 2019; Lowe, 2020; see also Braine, 2010), with few studies exploring this culturist ideology in a comprehensive way. Drawing on the research on this topic, this article attempts to display a panorama of native speakerism by further unearthing its ideological essence as well as its concomitant fallacies in four dimensions of ELT concerning English language teachers, English language standard, cultural orientation of ELT curriculum and teaching methodology. It is expected that this disinvention endeavor can help ELT stakeholders to develop a comparatively thorough and all-round understanding of native speakerism, particularly the fallacious nature of native speakerist practices in everyday ELT.

\section{The Ideological Essence of Native Speakerism and Its Side Effects on ELT}

\subsection{The Essence of Native Speakerism}

Ideology is of social origin, constructed by and constitutive of social structure (Fairclough, 2003). Native speakerism as an ideology should be viewed in reference to the social, historical, cultural and political nexus in the English speaking West or Inner Circle countries where it is emanated as well as the relevant context of Outer and Expanding Circle countries where it is reproduced, consolidated and/or contested.

Focusing on the social context of the English speaking West, many scholars (e.g., Holliday, 2005, 2015; Kumaravadivelu, 2012, 2016; Pennycook, 1998; Phillipson, 1992) maintain that native speakerism reflects the continuity of the colonialist Self versus Other dichotomy. Like other colonialist constructs, it is discursively constructed and "tangled up in configurations of power and ideology" (Kabel, 2009, p. 17). Holliday (2005) describes it as the ELT version of 'culturism', a term he coined to denote "any thought or act which reduces a person to something less than what [he or] she is according to an essentialist view of culture" (p. 17). Culturism, as he further notes, falls into the broad category of chauvinism and is constructed out of the dynamics of cultural essentialism, colonialism, Orientalism, the cultural politics of Self versus Other, and reification (Holliday, 2005, pp. 17-23). The essentialist perception of the world takes culture as a discrete, heterogeneous, monolithic or fixed entity. Colonialism constructs a binary division between a modern Self and a primitive Other as well as an illusionary moral mission on the part of the Self to civilize the Other by correcting their perceived uncivilized, primitive and backward cultural behaviors. Orientalism as a legacy of colonialism constructs the Orient as a 
problematic Other through unilateral arbitrary and imaginary narratives about the Orient (Said, 1979). When the joint product of these ideologies becomes reified, misrecognition ensues, namely, culturism becomes backgrounded or invisible as if it were objective, natural and exempted from human interventions. This is how culturism is reproduced, transmitted, consumed.

In ELT, the well-entrenched Self versus Other dichotomy of native speaker (NS) and nonnative speaker (NNS) is a typical representation of culturism. Native English speaker teachers (NESTs) are in general viewed as representatives of an advanced educational culture and hence expert teachers of English, with the moral mission and capability to edify or civilize nonnative students and colleagues (Holliday, 2005, 2015). However, culturism may not suffice for covering all the formative elements of native speakerism, which is also imbricated with either explicit or implicit racism (Houghton \& Rivers, 2013; Ruecker \& Ives, 2015). Exemplified are the cases that White Anglo-Saxon Protestants (WASPs) are generally upheld as the owner of English and Inner Circle culture (Kubota \& Lin, 2006; Shuck, 2006). In this logic, native speakerism is intertwined with racism and other above-stated 'isms' that reside in the wide spectrum of chauvinism.

Although native speakerism originates from the historical-political context of the English speaking west, inter alia, the culture of applied linguistics and ELT in those countries, it has been widely accepted by ELT profession of Outer and Expanding Circle countries, with itself modelled into a dominating ideology in global ELT (Holliday, 2005). Two factors are observed to account for this dissemination. One relates to the historical-present power imparity among the three Circles, which, to a great degree, justify and enact constantly the hegemony of former colonizers and the subalternity of the colonized (Kumaravadivelu, 2016; Pennycook, 1998). The other rests with the widespread denial or negligence of native speakerism as a pernicious ideology among ELT stakeholders due to the impact or colonization of modernist epistemology and its concomitant empirical-cum-positivistic practice followed in ELT pedagogy and research (Holliday \& Aboshiha, 2009).

\subsection{Pernicious Effects of Native Speakerism}

Ideology is power-driven and invested with interests (Fairclough, 2003). The reification or naturalization of native speakerism has produced multifaceted adverse effects on global ELT.

One of the pernicious effects is the massive dissemination of native speakerist discourses about the dichotomization of NS and NNS cultures. Native English speakers are portrayed with positive cultural and professional qualities, such as being 'independent', 'autonomous', 'individualist', 'critical' and/or 'modern'. By contrast, nonnative English speaker teachers and learners are depicted as being 'dependent', 'hierarchical', 'collectivist', 'obedient', 'uncritical', among others (Holliday, 2006, pp. 385-386), though these characteristics are also observed in classrooms of Inner Circle countries and that the orientation to criticality is also part of the education tradition of the Orient (Kumaravadivelu, 2003). Inner Circle teaching methodology, particularly the approach of communicative language teaching (CLT) and its updated form, task-based language teaching (TBLT), are claimed to be articulators of modern and advanced education culture (Kumaravadivelu, 2006; Richards \& Rodgers, 2014). In addition, Inner Circle English, particularly Anglo-American English, are hailed as Standard English (StE) vis-à-vis NNS English, which is famed as a 'half-baked bakery' (Quirk, 1990, p. 9), a metaphor adopted in general to nullify the legitimacy of Outer Circle English and by extension that of all nonnative English varieties (Rajagopalan, 2005; Saraceni, 2010, 2015).

In terms of native speakerism, what is more troubling is "the amalgamation of discursive hegemony and the various actualities that it rationalizes and sustains" (Kabel, 2009, p. 17). For instance, alongside the prevailing discourse that a NEST "inherently possesses a superior command of the language and intimate knowledge of the culture" (Breckenridge, 2010, p. 21), nonnative English speaker teachers (NNESTs) often encounter discriminations at job market and/or at workplace, where priority, prestige and preference tends to be granted to their native counterparts. Such prejudiced practices abound not only in Inner Circle contexts (e.g., Clark \& Paran, 2007; Mahboob, et al., 2004), but are more serious in Outer and Expanding Circle settings (e.g., Doan, 2016; Jeon \& Lee, 2006). Earlier, Govardhan, Nayar, and Sheorey (1999) analyzed 237 advertisements for English teaching posts in Outer and Expanding Circle contexts, finding that the main and even the only requirement is that applicants should be native English speakers or reach NS-like competence. Furthermore, native English speakers are usually referred to as those from Inner Circle countries (Seargeant, 2012). This is evident in a recent study by Mahboob and Golden (2013), who found that $79 \%$ of the 77 advertisements analyzed (42 from East Asia and 35 from the Middle East) use the term 'native speakers from Inner Circle countries' specifically. At workplace, NNESTs tend to encounter institutional discrimination, such as getting lower payment than NESTs, though they undertake the same workload as their native counterparts (Liu \& $\mathrm{Li}, 2019$ ) or being allocated to posts which are deemed less prestigious or less honorable professionally (Kubota \& Lin, 2006). As a corollary, 
the "unprofessional favoritism" (Medgyes, 2001) for NESTs tends to generate negative self-perceptions or a psychological complex of inferiority on the part of many NNESTs, and this in turn impedes their professional development.

In addition to discrimination against NNESTs, the "nativeness principle" (Levis, 2005) affect other aspects of ELT concerning language standard, cultural orientation and teaching methodology. To be specific, NS language norms, particularly "Received pronunciation" (RP) and/or "General American" (GA) accent, are taken by default as the pedagogical reference or target, regardless of the accelerating globalization of English in the current world (Bolton, 2008; Jenkins, 2012). Most teaching materials are embedded in Inner Circle culture, with nonnative cultures placed in the margin (Byram, 1988; McKay, 2012). The center-based teaching approaches, particularly CLT/TBLT at the current stage, are widely promoted in global ELT, with scant attention attached to educational cultures in variegated and various places (Bax, 2003; Kumaravadivelu, 2006). All these practices enhance the "epistemologies, knowledges, and practices that privilege the European modernist White civilization" (Scheurich, 1997, recited from Kubota \& Lin, 2006). The eco-system of "a nice field of TESOL" (Kubota, 2002) is therefore devastated.

Given that teacher, language norm, culture orientation and teaching methodology, are core elements in everyday ELT practice, the following section attempts to unearth respectively the fallacies of endorsing NESTs, NS English, NS culture and Inner Circle teaching approaches or methods in order to expose comprehensively the chauvinistic essence of native speakersim.

\section{Fallacies of Endorsing NESTs, NS English, NS Culture and NS Teaching Methodology}

\subsection{Fallacy of Idealizing NESTs}

Voices that debunk "the NS fallacy" (Phillipson, 1992, p. 185) fall into two categories. The first mainly emanates out of the theoretical explorations of the NS construct, and the second derives mostly from the studies on the respective pedagogical competence of NESTs and NNESTs.

The NS construct is considered traceable to the Chomskyan "ideal native speaker", who is asserted to possess complete and sound knowledge of his/her mother tongue and can therefore serve as a reliable or authoritative source of the language (Chomsky, 1965). This theoretical construct is adopted later by second language acquisition (SLA) academia. The classical SLA constructs, such as "interlanguage theory" and "fossilization" (Selinker, 1972) as well as "interaction hypothesis" (Long, 1983), all hold as the ultimate goal the acquisition of NS or NS-like competence. This drives mainstream SLA research methodology into a "comparative fallacy" (Bley-Vroman, 1983, recited from McKay, 2003), i.e., measuring the L2 output of L2 learners against the linguistic performance of L1 speakers (Bhatt, 2002; Cook, 1999, 2016). The NS status is further enhanced by the construct of "communicative competence" (Hymes, 1972) and its related CLT/TBLT approach promoted in ELT since 1970s (Kramsch, 1997). Influenced by these theoretical purports and practices, "the native speaker's 'competence' or 'proficiency' is [accepted by default as] the necessary point of reference for the second language proficiency concept in language teaching" (Stern, 1983, p. 341), resulting in the devaluation and stigmatization of nonnative speakers. As Firth and Wagner (1997) put it,

These concepts prefigure as monolithic elements in SLA, their status venerated and seemingly assured within the field. We claim that, for the most part, they are applied and understood in an oversimplified manner, leading, among other things, to an analytic mindset that elevates an idealized "native" speaker above a stereotypicalized "nonnative," while viewing the latter as a defective communicator, limited by an underdeveloped communicative competence (pp. 757-758).

Other scholars, such as Rajagopalan (2004) have questioned the validity of NS identity, namely who is a native speaker, asserting that it is more of a social construct than a linguistic one. Davies (2003) argues that three criteria, i.e., linguistic proficiency, self-identification and other-recognition, are often referred to in judging NS identity. Empirical studies (e.g., Inbar-Lourie, 2005), however, suggest a gap between self-identification and other-recognition due to the impact of variables, such as race, ethnicity and color other than language competence. Nonnative English speaking Caucasians are often mistaken for native English speakers while native English speakers from other ethnic or racial backgrounds tend to be misrecognized as nonnative (Braine, 2010; Brutt-Griffler \& Samimy, 2001). Rampton (1990) questions another set of tripartite criteria - language expertise, language affiliation, and language inheritance - that are accepted widely for measuring "nativeness". As he argues, on the one hand, expertise does not necessarily entail inheritance and inheritance may not guarantee affiliation; on the other hand, the concept of language expertise faces challenges in the current globalized world where multilingualism has become the zeitgeist. Even if a native speaker possesses innate linguistic competence, a nonnative speaker can achieve native-like competence through hard work and proper training (Davies, 2003). 
In the current multilingual world, the term, "native speaker" should be replaced by "expert speaker" (Rampton, 1990) "multi-competent user" (Cook, 1999) or "successful bilingual" (Prodromou, 2006). Since the NS concept is sustained by "no scientific validity" (Phillipson, 1992, p. 195), the pro-NESTs ideology and practices are fallacious in nature.

The other category of discourses countering "the NS fallacy" (Phillipson, 1992, p. 185) comes from studies on the pedagogical competence of NESTs and NNESTs, particularly the studies synchotnized with the NNEST Movement (Braine, 2010; Mahboob, 2010). As stated previously, NS is usually depicted as the representative of an advanced culture, while the NNS is frequently portrayed in the image of a tribal, backward or primitive barbarian (Holliday, 2005; Pennycook, 1998). These so-called cultural traits of the nonnative group construct discursively NNESTs as incompetent or undesirable professionals (Doan, 2016, p. 68). Scholars, such as Medgyes (1994) argue that NNESTs possess qualities or merits of which NESTs are lack. To be specific, NNESTs can be a successful model for English learners, teach learners learning strategies more effectively, predict students' learning difficulties, and supply students with more metalinguistic knowledge, in addition to being more sympathetic with students' needs and learning problems, and being able to utilize L1 that is shared with students. Other scholars, such as Braine (2010), assert that qualified language teachers must have, apart from the knowledge of pedagogy, methodology, and applied linguistics, what Fairclough (1995) terms as "critical language awareness" or a transformative consciousness about education (McLaren, 2015). Since these qualities are acquired via education, a NS cannot become a qualified English teacher automatically (Canagarajah, 1999; Rampton, 1990). As such, the discourse of NS as the ideal teacher needs to be demythologized.

\subsection{Fallacy of Supporting Inner Circle English}

In addition to exposing the fallacy of idealizing NESTs, another strand of discourse poses challenges to the long-established assumption about the ownership of English and the linguistic superiority of NS English. This critiquing flame is mainly ignited and fanned by the scholarship on the globalization of English, including English as an international language (EIL; McKay \& Bokhorst-Heng, 2008; Smith \& Nelson, 1985), World Englishes (WE; Kachru, 2005; Tupas, 2015), and English as a lingua franca (ELF; Jenkins, 2007; Seidlhofer, 2011).

The rationale underpinning the discourses that challenge the traditional conceptualization on the ownership of English mostly resides in the demographic change of English speakers and the actual use of English around the globe. Out of the political, economic and cultural factors both in history and in the contemporary world, English has traversed across the globe and evolved into an international language and even an intra-national lingua franca in traditionally nonnative English speaking countries, making native English speakers a minority among all English speakers (Graddol, 2006). According to Crystal (2003), all English speakers or users are currently estimated to make up a third of the world population, reaching somewhere between 1.1 billion to 1.8 billion, of which only 320 million to 380 million are native speakers of English (p. 61). A recent statistical figure suggests that in Asia alone, nonnative English users have reached beyond 800 million, more than the population of Inner Circle countries combined (Bolton et al., 2011, recited from Ahn, 2014). Alongside its global expansion, English has undergone accommodation and/or nativization to meet both international and local needs. In this sense, English has become "de-nationalized" (Smith, 1992), "re-nationalized" (McKay, 2012) and "relocated" (Saraceni, 2010), making itself no longer the property of NS. Nonnative English speakers should thereby be admitted as legitimate owners and even future producers of English. This sociolinguistic landscape ensures the reverberation of the radical statement made earlier by Widdowson (1994) on English being owned by its native and nonnative speakers.

The scholarship on the globalization of English also debunks the assumed prestigious qualities of NS English, i.e., authenticity, intelligibility and wide applicability. Firstly, that NS English is the most authentic is asserted as a misinterpretation of authenticity. According to Lowe and Pinner (2016), authenticity, as a socio-psychological construct, refers to "the way an individual sees themselves in relation to the various contexts in which they exist and are required to use language for social production of meaning" (p. 36). Following this definition, authenticity is relativistic and context-specific, and any use of English by any individual in any specific context at any time can be regarded as authentic English. Hence, it is native speakerism that underpins the contrast of NS English claimed as authentic to NNS English stigmatized as inauthentic. Secondly, the claim that NS English is most intelligible fails to take into account the essence of intelligibility. In reference to Smith (1992, p. 76), intelligibility includes three senses: intelligibility (recognizing word/utterance), comprehensibility (recognizing the semantic meaning of word/utterance) and interpretability (recognizing the pragmatic meaning of word/utterance). Implied by this perception is that it is people rather than language itself that matters more to intelligibility, as the familiarity of a speaker with an English variety determines the degree of its intelligibility 
(Smith, 1992; Smith \& Nelson, 1985). In this logic, the familiarization with different English varieties should be a prerequisite for successful communication in English in the current world where English has developed into an international language and where native and nonnative users are constantly reconstructing or remodeling it (Canagarajah, 2007; Kirkpatrick, 2007). Empirical studies also indicate that nonnative English varieties do not affect intelligibility and comprehensibility. For example, Derwing \& Munro (1997; recited from Scales et al., 2006) found that their research subjects, (native English speakers from Canada) are able to understand NNS accent and even able to transcribe exactly most of the accented speech. Thirdly, $80 \%$ of the communications in English are estimated to take place between or among nonnative English speakers in the current world (Graddol, 2006; Sharifian, 2013). This sociolinguistic context cannot guarantee the efficient and effective applicability of NS English.

Given this sociolinguistic reality, the conventional and still persistent fervent support of NS English is fallacious in nature. The mere adherence to NS norms in ELT does not only grant NS the prerogative to decide which English is intelligible and which is not (Bamgbose, 1998), but also exercise discrimination against nonnative English (Sowden, 2012) and set up an unattainable and thereby frustrating goal for most English language learners (Kirkpatrick, 2007).

\subsection{Fallacy of Sustaining NS Culture}

Conventionally, ELT curricular materials are embedded NS culture, particularly Anglo-American culture (Brown, 2007; Kumaravadivelu, 2008). This monocultural orientation has encountered multi-pronged criticisms, with its fallacy exposed.

Politically, the overwhelming representation of Inner Circle culture in ELT curricula contributes to reinforcing cultural inequalities between the Occident and the Orient. Many researchers have pointed out that these practices represent the ideology of linguistic imperialism (Phillipson, 1992) and cultural chauvinism (Holliday, 2005) and colonialism (Pennycook, 1998), whose joint efforts render non-Western culture devalued, subjugated, silenced and even undermined (Modiano, 2001; Phan, 2008). In the meantime, this one-sided cultural practice may lead to a perception that Inner Circle culture only comprises Anglo-American culture and that learners will not communicate with English speakers from beyond the geographic boundary of America and Britain (Nault, 2006). It follows that the culture of other Inner Circle countries are rendered voiceless (Blum \& Johnson, 2012). Furthermore, ELT curricular materials, particularly those commercially produced for international users, mainly present the middle class WASP culture regardless of cultural diversity in Britain and America (Gray, 2010), leaving off at the same time trouble spots of Inner Circle societies and producing in turn an imaginary Eden-like image of Anglo-American culture (Akbari, 2008, p. 281).

Socio-linguistically, the over-emphasis on Anglo-American culture in ELT counters the globalization of English in the current world. Currently, international communications in English are mostly between or among nonnative English speakers in settings or contexts that have no relation to Anglo-American Culture (Cogo, 2012; Dewey \& Jenkins, 2010). It follows that monocultural ELT practices in favor of Anglo-American cultural norms falls behind the times. The shift to a more inclusive and pluralistic cultural paradigm in ELT in line with the current sociolinguistic and sociocultural situation of English is a necessity (Canagarajah, 2014; Kumaravadivelu, 2012).

Pedagogically, the monocultural orientation of ELT curricula may prevent the acquisition of English in terms of of many learners of English. According to Widdowson (1990, recited from Alptekin, 1993, pp. 136-137), a person needs "schematic knowledge" (social knowledge) and "systemic knowledge" (linguistic knowledge) in dealing with language input. When learning English as a foreign or second language, it is inevitable for learners to encounter linguistic difficulties. The teaching and learning materials embedded in Anglo-American culture constitute additional cognitive obstacles to learners, because most learners do not possess the socially acquired schematic knowledge of English. Moreover, learners may feel alienated and then lose learning interests, as most of the culture is far from their lived experiences (Gong \& Holliday, 2013). They may develop biased attitudes toward Outer and Expanding Circle cultures that are denigrated explicitly or silenced in ELT textbooks, as textbooks are often regarded as a reliable, authoritative and legitimate source of knowledge, by virtue of which students and even teachers position themselves and (dis)identify with certain cultural norms (Duff \& Uchida, 1997, recited from Ilieva, 2000). In addition, the imbalanced cultural representation neglects the diversity, hybridity and fluidity of culture, violates the spirit of transformative education, and prevents English language learners from developing intercultural awareness (Baker, 2011; Kumaravadivelu, 2008).

Fallacious as this monocultural orientation is, it does not mean that Anglo-American culture should be excluded from ELT. In response to the sociolinguistic reality of English, many suggestions have been advanced. For example, Cortezzi and Jin (1999) propose that three types of culture should be incorporated in ELT textbooks or 
instructional materials, namely, the target culture (Inner Circle culture), the source culture (learners' national culture) and the international culture (cultures of non-English-speaking countries). Similarly, Matsuda and Friedrich (2011) suggest teaching global culture (culture of different countries, including Inner Circle culture), culture of prospective interlocutors, and source culture (learners' own local or national culture).

\subsection{Fallacy of Favoring CLT/TBLT}

Humanistic as it seems to be in philosophical orientation, CLT/TBLT is a discourse of marginalization and the enthusiastic of promotion of CLT/TBLT in global ELT is a fallacy.

Firstly, CLT/TBLT marginalizes NNS language and culture. Communicative competence, upheld as the objective of CLT/TBLT, asks learners to acculturate in mind to the target language community (Kumaravadivelu, 2006). Implied from this stance is that learners must imitate NS linguistic and cultural behaviors and that learners' own language and culture are obstacles to their developing communicative competence in English. This stance is further reinforced by the asserted principle and practice of adopting authentic instructional materials, which are synonymous with texts or discourses produced by native English speakers (Kramsch, 1998; Widdowson, 1998). It is also consolidated by the English-only thesis and its related popular claim that "L1 use is incompatible with a communicative approach" (McMillan \& Rivers, 2011, p. 253). In this logic, CLT/TBLT resonates with the traditional 'monolingual tenet' in ELT (Phillipson, 1992, p. 192) and has ideological and structural consequences. Ideologically, it serves to strengthen the superiority of NS English over the mother tongue of English learners and even deprives them of their cultural identity and linguistic heritage; structurally, it ensures the sales and marketing of monolingual teaching and learning materials developed by the Centre and creates a great number of employment opportunities for NS teachers (Phillipson, 1992, pp. 192-193). Moreover, CLT/TBLT is detrimental since it "undermines the productive use of the mother tongue in the learning of English, which is particularly problematic in an era when English is primarily learned in bilingual classrooms" (McKay, 2003, p. 17).

Secondly, CLT/TBLT devalues Outer and Expanding Circle education culture. CLT/TBLT adopts the "learning group ideal" or 'learner-centered tenet' (Holliday, 2005), the methodologically proper in Inner Circle countries. The promotion of CLT/TBLT by Inner Circle ELT agencies echoes the colonialist story of Robinson Crusoe's 'civilizing' Man Friday (Pennycook, 1998, pp. 10-16) or reverbrates the "native-speakerist 'moral mission' to bring a 'superior culture of teaching and learning to [nonnative] students and colleagues who are perceived not to be able to succeed on their own" (Holliday, 2006, p. 386). It is in fact an agenda aimed to correct the assumed backwardness in learning behavior of nonnative English learners. The Centre seems unable to realize that "the choice of communicative language teaching as a goal was possibly a sort of naïve ethnocentrism promoted by the thought that what is good for Europe or the USA had to be good for Kwa Zulu" (Chick, 2006, recited from Kumaravadivelu, 2006, p. 63). In terms of nonnative English speaking countries, their whole-heartedly adopting this seemingly humanistic and egalitarian approach is in fact a form of self-oppression (Kumaravadivelu, 2003). Considering that education is context-embedded, the 'Learner-centered' or 'Group- or Pair-work' teaching model may not apply to all contexts. In this logic, pedagogical approaches, such as "Context Approach" (Bax, 2003), "appropriate methodology" (Holliday, 1994), "appropriate pedagogy" (Kramsch \& Sullivan, 1996), or "post-method approach" (Kumaravadivelu, 2006), should be adopted in global ELT.

Thirdly, CLT/TBLT, like other Inner Circle teaching approaches, represents and safeguards the hegemony of Inner Circle scholarship. Given that knowledge is interested by nature and serves inequitable power relationships (Pennycook, 1998), CLT, constructed by Inner Circle applied linguistics and ELT, exemplifies the worldviews of Inner Circle academia. Especially, it cannot escape totally from the culturist ethos in Inner Circle societies that valorizes Western knowledge system (Holliday, 2005; Phan, 2008). In this sense, the promotion of CLT, either by the Centre or the Periphery, contributes to reproducing Western pedagogical imperialism in ELT. Albeit this, Inner Circle experts or institutes continue to promote CLT/TBLT, and surprisingly Outer and Expanding Circle governments, particularly those of the Asia-Pacific region and East Asia, adopt CLT/TBLT as a default ELT approach (Nunan, 2003), making themselves the consumer and implementer of Center-interested academic products (Phan, 2014).

\section{Discussion}

This article explores native speakerism in reference to a wide range of literature on NNEST Movement, the globalization of English, multicultural education and post-method studies. It disinvents the ideological nature of native speakerism and its pernicious impacts on ELT ecology, and deconstructs the fallacies of ELT practices that sustain the superiority of NESTs, NS English, NS culture and NS teaching methodology. Inferred from this critical review, native speakerism is a joint-product of the historically continuing and still persistent cultural 
hegemony of the English speaking West and the self-discrimination of Outer and Expanding Circle countries. Implied also is that the core of native speakerism resides in the conventional ideology that native English speakers are the owners of English and possess an advanced education culture.

Given the tenacity of native speakerism in ELT across the globe and the rich sociolinguistic and sociocultural landscape engendered by globalization in the current world, ELT researchers need to work further to expose the fallacies of this conventional and still vibrating chauvinistic ideology in order to build up a more ethical, democratic and harmonious ELT ecology. It has to be admitted that this article as well as most literature reviewed in this study adopts as conceptual tools the terminologies, such as Inner Circle English and Inner Circle culture, as no language and culture are fixed, stable and totally discrete. Notwithstanding that, it may help to reproduce the banal nation-state-language-culture ideology among potential readers. Further studies are suggested to take into account this constructs to avoid reproducing the conventional essentialized sense of language and culture.

\section{References}

Ahn, H. (2014). Teachers' attitudes towards Korean English in South Korea. World Englishes, 33(2), 195-222. https://doi.org/10.1111/weng.12081

Akbari, R. (2008). Transforming lives: introducing critical pedagogy into ELT classrooms. ELT Journal, 62(3), 276-283. https://doi.org/10.1093/elt/ccn025

Baker, W. (2011). From cultural awareness to intercultural awareness: culture in ELT. ELT Journal, 66(1), 62-70. https://doi.org/10.1093/elt/ccr017

Bamgbose, A. (1998). Torn between the norms: Innovations in world Englishes. World Englishes, 17(1), 1-14. https://doi.org/10.1111/1467-971X.00078

Bax, S. (2003). The end of CLT: A context approach to language teaching. ELT Journal, 57(3), 278-287. https://doi.org/10.1093/elt/57.3.278

Bhatt, R. M. (2002). Experts, dialects, and discourse. International Journal of Applied Linguistics, 12(1), 74-109. https://doi.org/10.1111/1473-4192.00025

Blum, A., \& Johnson, E. J. (2012). Reading repression: Textualizing the linguistic marginalization of nonnative English-speaking teachers in Arizona. Journal of Language, Identity \& Education, 11(3), 167-184. https://doi.org/10.1080/15348458.2012.686379

Bolton, K. (2008). English in Asia, Asian Englishes, and the issue of proficiency. English Today, 24(2), 3-12. https://doi.org/10.1017/S026607840800014X

Braine, G. (2010). Nonnative speaker English teachers: Research, pedagogy and professional growth. Wiley Online Library. https://doi.org/10.4324/9780203856710

Breckenridge, Y. M. (2010). Professional identity and the 'native speaker': An investigation of essentializing discourses in TESOL. Unpublished Ph.D dissertation. Edmonton, Alberta: University of Alberta.

Brown, H. D. (2007). Principles of language learning and teaching (5th ed.). New York: Pearson Education.

Brutt-Griffler, J., \& Samimy, K. K. (2001). Transcending the nativeness paradigm. World Englishes, 20(1), 99-106. https://doi.org/10.1111/1467-971X.00199

Byram, M. (1988). Foreign language education and cultural studies. Language, Culture and Curriculum, 1(1), 15-31. https://doi.org/10.1080/07908318809525025

Canagarajah, A. S. (1999). Interrogating the "native speaker fallacy": Non-linguistic roots, non-pedagogical results. In G. Braine (Ed.), Non-native educators in English language teaching (pp. 77-92). Mahwah, NJ: Lawrence Erlbaum.

Canagarajah, A. S. (2007). Lingua franca English, multilingual communities, and language acquisition. The Modern Language Journal, 91(1), 923-939. https://doi.org/10.1111/j.1540-4781.2007.00678.x

Canagarajah, A. S. (2014). In search of a new paradigm for teaching English as an international language. TESOL Journal, 5(4), 767-785. https://doi.org/10.1002/tesj.166

Chomsky, N. (1965). Aspects of the Theory of Syntax. Cambridge, MA: MIT Press. https://doi.org/10.21236/AD0616323

Clark, E., \& Paran, A. (2007). The employability of non-native-speaker teachers of EFL: A UK survey. System, 35(4), 407-430. https://doi.org/10.1016/j.system.2007.05.002 
Cogo, A. (2012). English as a lingua franca: Concepts, use, and implications. ELT Journal, 66(1), 97-105. https://doi.org/10.1093/elt/ccr069

Cook, V. (1999). Going beyond the native speaker in language teaching. TESOL Quarterly, 33(2), 185-209. https://doi.org/10.2307/3587717

Cook, V. (2016). Where Is the Native Speaker Now? TESOL Quarterly, 50(1), 186-189. https://doi.org/10.1002/tesq.286

Cortezzi, M., \& Jin, L. (1999). Cultural mirrors: Materials and methods in the EFL clasroom. In H. E (Ed.), Culture in Second Language Teaching and Learning (pp. 196-219). Cambridge: Cambridge University Press.

Crystal, D. (2003). English as a global language (2nd ed). Cambridge: Cambridge University Press. https://doi.org/10.1017/CBO9780511486999

Davies, A. (2003). The Native Speaker: Myth and reality. Clevedon: Multilingual Matters. https://doi.org/10.21832/9781853596247

Dewey, M., \& Jenkins, J. (2010). English as a lingua franca in the global context: Interconnectedness, variation and change. In M. Saxena (Ed.), Contending with globalization in World Englishes (pp. 72-92). Clevedon, UK: Multilingual Matters. https://doi.org/10.21832/9781847692764-007

Doan, N. B. (2016). To employ or not to employ expatriate non-native speaker teachers: views from within. Asian Englishes, 18(1), 67-79. https://doi.org/10.1080/13488678.2015.1132112

Fairclough, N. (1995). Critical discourse analysis: The critical study of language. London: Longman.

Fairclough, N. (2003). Analysing discourse: Textual analysis for social research. London and New York: Routledge. https://doi.org/10.4324/9780203697078

Firth, A., \& Wagner, J. (1997). On discourse, communication, and (some) fundamental concepts in SLA research. The Modern Language Journal, 81(3), 285-300. https://doi.org/10.1111/j.1540-4781.1997.tb05480.x

Gong, Y., \& Holliday, A. (2013). Cultures of change: Appropriate cultural content in Chinese school textbooks. In K. Hyland \& L. L. C. Wong (Eds.), Innovation and Change in English Language Education (pp. 44-57). New York: Routledge.

Govardhan, A. K., Nayar, B., \& Sheorey, R. (1999). Do US MATESOL Programs Prepare Students to Teach Abroad? TESOL Quarterly, 33(1), 114-125. https://doi.org/10.2307/3588194

Graddol, D. (2006). English next. London: The British Council.

Gray, J. (2010). The branding of english and the culture of the new capitalism: representations of the world of work in english language textbooks. Applied Linguistics, 31(5), 714-733. https://doi.org/10.1093/applin/amq034

Holliday, A. (1994). Appropriate methodology and social context. Cambridge: Cambridge University Press.

Holliday, A. (2005). The struggle to teach English as an international language. Cambridge: Cambridge University Press.

Holliday, A. (2006). Native speakerism. ELT Journal, 60(4), 385-387. https://doi.org/10.1093/elt/ccl030

Holliday, A. (2015). Native speakerism: taking the concept forward and achieving cultural belief. In A. Swan, P. Aboshiha \& A. Holliday (Eds.), (En)Countering Native speakerism: Global Perspectives (pp. 11-25). UK: Palgrave Macmillan. https://doi.org/10.1057/9781137463500_2

Holliday, A., \& Aboshiha, P. (2009). The denial of ideology in perceptions of 'Nonnative Speake'teachers. TESOL Quarterly, 43(4), 669-689. https://doi.org/10.1002/j.1545-7249.2009.tb00191.x

Houghton, S. A., \& Rivers, D. J. (2013). Introduction: Redefining Native speakerism. In S. A. Houghton \& D. J. Rivers (Eds.), Native speakerism in Japan: Intergroup dynamics in foreign language education (pp. 1-14). Bristol, Buffalo, Toranto: Multilingual Matters. https://doi.org/10.21832/9781847698704-004

Hymes, D. (1972). On communicative competence. In J. B. Pride \& J. Holmes (Eds.), Sociolinguistics: Selected readings (pp. 269-293). Harmondsworth: Penguin.

Ilieva, R. (2000). Exploring Culture in Texts Designed for Use in Adult ESL Classrooms. TESL Canada Journal, 17(2), 50-63. https://doi.org/10.18806/tesl.v17i2.889 
Inbar-Lourie, O. (2005). Mind the gap: Self and perceived native speaker identities of EFL teachers. In E. Llurda (Ed.), Non-native language teachers (pp. 265-281). New York: Springer. https://doi.org/10.1007/0-387-24565-0_14

Jenkins, J. (2007). English as a Lingua Franca: Attitude and Identity. Oxford: Oxford University Press.

Jenkins, J. (2012). English as a Lingua Franca from the classroom to the classroom. ELT Journal, 66(4), 486-494. https://doi.org/10.1093/elt/ccs040

Jeon, M., \& Lee, J. (2006). Hiring native-speaking English teachers in East Asian countries. English Today, 22(4), 53. https://doi.org/10.1017/S0266078406004093

Kabel, A. (2009). Native speakerism, stereotyping and the collusion of applied linguistics. System, 37(1), 12-22. https://doi.org/10.1016/j.system.2008.09.004

Kachru, B. B. (2005). Asian Englishes: beyond the canon. Hong Kong: University Press.

Kirkpatrick, A. (2007). Setting attainable and appropriate English language targets in multilingual settings: A case for Hong Kong. International Journal of Applied Linguistics, 17(3), 376-391. https://doi.org/10.1111/j.1473-4192.2007.00170.x

Kramsch, C. (1998). Language and culture. Oxford: Oxford University Press.

Kubota, R. (2002). The Author Responds: (Un) raveling racism in a field like TESOL. TESOL Quarterly, 36(1), 84-92. https://doi.org/10.2307/3588363

Kubota, R., \& Lin, A. (2006). Race and TESOL: Introduction to concepts and theories. TESOL Quarterly, 40(3), 471-493. https://doi.org/10.2307/40264540

Kubota, R., \& Lin, A. M. (2009). Race, culture, and identities in second language education: Exploring critically engaged practice. New York: Routledge. https://doi.org/10.4324/9780203876657

Kumaravadivelu, B. (2003). Problematizing cultural stereotypes in TESOL. TESOL Quarterly, 37(4), 709-719. https://doi.org/10.2307/3588219

Kumaravadivelu, B. (2006). Understanding language teaching: From method to postmethod. New York: Routledge. https://doi.org/10.4324/9781410615725

Kumaravadivelu, B. (2008). Cultural globalization and language education. New Haven: Yale University Press.

Kumaravadivelu, B. (2012). Individual identity, cultural globalization, and teaching English as an international language. In L. Alsagoff, S. L. Mackay, G. Hu, \& W. A. Renandya (Eds.), Principles and practices for teaching English as an international language (pp. 9-27). New York: Routledge.

Kumaravadivelu, B. (2016). The Decolonial Option in English Teaching: Can the Subaltern Act? TESOL Quarterly, 50(1), 66-85. https://doi.org/10.1002/tesq.202

Levis, J. M. (2005). Changing contexts and shifting paradigms in pronunciation teaching. TESOL Quarterly, 39(3), 369-377. https://doi.org/10.2307/3588485

Liu, J., \& Li, S. (2019). Native-speakerism in English Language Teaching: The current situation in China. Newcastle upon Tynne: Cambridge Scholars Publishing.

Long, M. H. (1983). Native speaker/non-native speaker conversation and the negotiation of comprehensible input. Applied Linguistics, 4(2), 126-141. https://doi.org/10.1093/applin/4.2.126

Lowe, R. J. (2020). Uncovering Ideology in English Language Teaching: Identifying the 'Native Speaker' frame. Switzerland AG: Springer. https://doi.org/10.1007/978-3-030-46231-4

Lowe, R. J., \& Pinner, R. (2016). Finding the connections between native speakerism and authenticity. Applied Linguistics Review, 7(1), 27-52. https://doi.org/10.1515/applirev-2016-0002

Mahboob, A. (2010). The NNEST lens: Non native English speakers in TESOL. Cambridge Scholars Publishing.

Mahboob, A., \& Golden, R. (2013). Looking for native speakers of English: Discrimination in English language teaching job advertisements. Voices in Asia, 3(18), 72-81.

Mahboob, A., Uhrig, K., Newman, K., \& Hartford, B. (2004). Children of a lesser English: Nonnative English speakers as ESL teachers in English language programs in the United States. In L. D. Kamhi-Stein (Ed.), Learning and teaching from experience: Perspectives on nonnative English-speaking professionals (pp. 100-120). Ann Arbor: MI University of Michigan Press. 
Matsuda, A., \& Friedrich, P. (2011). English as an international language: A curriculum blueprint. World Englishes, 30(3), 332-344. https://doi.org/10.1111/j.1467-971X.2011.01717.x

McKay, S. L. (2003). Teaching English as an international language: The Chilean context. ELT Journal, 57(2), 139-148. https://doi.org/10.1093/elt/57.2.139

McKay, S. L. (2012). Teaching materials for English as an international language. In A. Matsuda (Ed.), Principles and practices of teaching English as an international language (pp. 70-83). Bristol, Buffalo, Toronto: Multilingual Matters. https://doi.org/10.21832/9781847697042-007

McKay, S. L., \& Bokhorst-Heng, W. D. (2008). International English in its sociolinguistic contexts: Towards a socially sensitive EIL pedagogy. New York: Routledge.

McLaren, P. (2015). Life in schools: An introduction to critical pedagogy in the foundations of education. New York: Routledge. https://doi.org/10.4324/9781315633640

McMillan, B. A., \& Rivers, D. J. (2011). The practice of policy: Teacher attitudes toward "English only". System, 39(2), 251-263. https://doi.org/10.1016/j.system.2011.04.011

Medgyes, P. (1994). The non-native teacher. London: Mcmillan.

Medgyes, P. (2001). When the teacher is a non-native speaker. In M. Celce-Murica, D. M. Brinton \& S. M. A (Eds.), Teaching English as a second or foreign language (pp. 429-442). Boston: Heinle \& Heinle.

Modiano, M. (2001). Linguistic imperialism, cultural integrity, and EIL. ELT Journal, 55(4), 339-347. https://doi.org/10.1093/elt/55.4.339

Nault, D. (2006). Going global: Rethinking culture teaching in ELT contexts. Language, Culture and Curriculum, 19(3), 314-328. https://doi.org/10.1080/07908310608668770

Nunan, D. (2003). The Impact of English as a Global Language on Educational Policies and Practices in the Asia-Pacific Region. TESOL Quarterly, 37(4), 589-613. https://doi.org/10.2307/3588214

Pennycook, A. (1998). English and the discourses of colonialism. London: Routledge.

Phan, L. H. (2008). Teaching English as an international language: Identity, resistance and negotiation. Clevedon, Buffalo, Torontao: Multilingual Matters.

Phan, L. H. (2014). The politics of naming: critiquing "learner-centred" and "teacher as facilitator" in English language and humanities classrooms. Asia-Pacific Journal of Teacher Education, 42(4), 392-405. https://doi.org/10.1080/1359866X.2014.956048

Phillipson, R. (1992). Linguistic imperialism. Oxford: Oxford University Press.

Prodromou, L. (2006). Bilingua Speaker'of English. In R. Rubdy \& M. Saraceni (Eds.), English in the world: Global rules, global roles (pp. 51-57). London: Continuum.

Quirk, R. (1990). Language varieties and standard language. English Today, 6(1), 3-10. https://doi.org/10.1017/S0266078400004454

Rajagopalan, K. (2005). Non-native speaker teachers of English and their anxieties: Ingredients for an experiment in action research. In E. Llurda (Ed.), Non-Native Language Teachers: Perceptions, Challenges, and Contributions to the Profession (pp. 283-303). New York: Springer. https://doi.org/10.1007/0-387-24565-0_15

Rampton, M. B. H. (1990). Displacing the 'native speaker': Expertise, affiliation, and inheritance. ELT Journal, 44(2), 97-101. https://doi.org/10.1093/elt/44.2.97

Richards, J. C., \& Rodgers, T. S. (2014). Approaches and methods in language teaching. Cambridge university press.

Ruecker, T., \& Ives, L. (2015). White native English speakers needed: the rhetorical construction of privilege in online teacher recruitment spaces. TESOL Quarterly, 49(4), 733-756. https://doi.org/10.1002/tesq.195

Said, E. (1978). Orientalism. London: Penguin.

Saraceni, M. (2010). The relocation of English: Shifting paradigms in a global era. Palgrave Macmillan. https://doi.org/10.1007/978-0-230-29691-6

Saraceni, M. (2015). World Englishes: a critical analysis. Bloomsbury Publishing. 
Scales, J., Wennerstrom, A., Richard, D., \& Wu, S. H. (2006). Language learners' perceptions of accent. TESOL Quarterly, 40(4), 715-738. https://doi.org/10.2307/40264305

Seargeant, P. (2012). Exploring world Englishes: Language in a global context. New York: Routledge. https://doi.org/10.4324/9780203115510

Seidlhofer, B. (2011). Understanding English as a lingua franca. Oxford University Press. https://doi.org/10.1002/9781405198431.wbeal0243

Selinker, L. (1972). Interlanguage. IRAL-International Review of Applied Linguistics in Language Teaching, 10(1-4), 209-232. https://doi.org/10.1515/iral.1972.10.1-4.209

Sharifian, F. (2013). Globalisation and developing metacultural competence in learning English as an International Language. Multilingual Education, 3(7), 1-11. https://doi.org/10.1186/2191-5059-3-7

Shuck, G. (2006). Racializing the nonnative English speaker. Journal of Language, Identity, and Education, 5(4), 259-276. https://doi.org/10.1207/s15327701jlie0504_1

Smith, L. E. (1992). Spread of English and issues of intelligibility. In B. B. Kachru (Ed.), The other tongue: English across cultures (pp. 75-90). Urbana, IL: University of Illinois Press.

Smith, L. E., \& Nelson, C. L. (1985). International intelligibility of English: Directions and resources. World Englishes, 4(3), 333-342. https://doi.org/10.1111/j.1467-971X.1985.tb00423.x

Sowden, C. (2012). ELF on a mushroom: the overnight growth in English as a Lingua Franca. ELT Journal, 66(1), 89-96. https://doi.org/10.1093/elt/ccr024

Stern, H. H. (1983). Fundamental concepts of language teaching: Historical and interdisciplinary perspectives on applied Linguistic research. Oxford: Oxford University Press.

Tupas, R. (Ed.). (2015). Unequal Englishes: The politics of Englishes today. New York: Palgrave Mcmillan. https://doi.org/10.1057/9781137461223

Widdowson, H. G. (1994). The ownership of English. TESOL Quarterly, 28(2), 377-389. https://doi.org/10.2307/3587438

Widdowson, H. G. (1998). Context, community, and authentic language. TESOL Quarterly, 32(4), 705-716. https://doi.org/10.2307/3588001

\section{Copyrights}

Copyright for this article is retained by the author(s), with first publication rights granted to the journal.

This is an open-access article distributed under the terms and conditions of the Creative Commons Attribution license (http://creativecommons.org/licenses/by/4.0/). 